\title{
Impact of Macroeconomic Variables on Karachi Stock Market Returns
}

\author{
Javed Pervaiz $^{1}$, Junaid Masih ${ }^{2} \&$ Teng Jian-Zhou ${ }^{1}$ \\ ${ }^{1}$ School of Economics, Northeast Normal University, Changchun, China \\ ${ }^{2}$ Nanjing University of Science \& Technology, Nanjing, Jiangsu, China \\ Correspondence: Javed Pervaiz, School of Economics, Northeast Normal University, Changchun, China. E-mail: \\ youy614@nenu.edu.cn
}

Received: November 6, 2017

Accepted: December 27, 2017

Online Published: January 5, 2018

doi:10.5539/ijef.v10n2p28

URL: https://doi.org/10.5539/ijef.v10n2p28

\begin{abstract}
The study examines the impact of selected macroeconomic variables (inflation, exchange rate, interest rate) on Karachi stock market returns. Mainly secondary data used in the research process. The study consists of data for the period of 10 years and 5 months starting from January 2007 till May 2017. For this purpose, monthly data of KSE-100 index has been observed for the period January 2007 to May 2017. The market returns have been calculated through the opening and closing index value of each month. The inflation, interest rate, and exchange rate has been taken as independent variables. Hypotheses have been tested to find out whether there exists a significant relationship between the Stock market return and macroeconomic variables or not. To test this hypothesis, Regression analysis used and results are calculated through Stata software.
\end{abstract}

Keywords: Pakistan, macroeconomic variables, KSE returns, stock prices

\section{Introduction}

The rapid growth in the equity market has fascinated investors as well as researchers, to study the volatile behavior of stock market returns as a result of different economic factors. Jessica A. wachter (2013) stated that potential yield of returns in equity market is comparatively higher. Equity market is not only an avenue for the investors but also a source of capital for the firms. The stock returns from equity market are highly influenced by multiple factors such as performance of that particular stock, overall market conditions, prevailing economic conditions, etc. The study of aforesaid variables is important enough to analyze the performance of the stocks. While, on the other side, increasing growth and importance of stock market has also opened a new horizon for the researchers. In this regard, the causal relationship between macroeconomic factors and volatility in stock market returns is the part of many researches. This type of studies enables the investors to make effective and efficient investment decisions and also helps the firms to improve their market worth. Though the impact of macroeconomic variables is noncontroversial but it is considerably difficult to examine which macroeconomic variables have pivotal influence in this context. While studying the behavior of stocks at Ghana Stock Exchange Coleman and Tettey (2012) concluded that interest rate, industrial production, inflation, etc. have significant influence on the stock returns. Fraser and Groenewold (2013) studied the impact of exchange rate fluctuations over stock returns in Australian equity market and came up with the conclusion that there exists a positive relation between both the aforesaid variables. Number of studies conducted in USA, Cyprus, Australia and Sri Lanka to find out the relationship between macroeconomic variables and the fluctuations of stock prices (Serfling \& Miljkovic, 2011; Bekiros \& Georgoutsos, 2008; Wickremasinghe, 2012; Fraser \& Groenewold, 2013). The findings of these studies show that with the minor variation these macroeconomic variables have the significant impact on stock prices. On the basis of previous researches we can say that there is a need to determine whether the volatility in stock returns is caused by macroeconomic variables or there are some other factors that influence its behavior? And it is also crucial to determine that the impact of macroeconomic factors is significant enough to test empirically. Lots of researches has been conducted on the issue in different countries (Bekiros \& Georgoutsos, 2008; Serfling \& Miljkovic, 2011; Fraser \& Groenewold, 2000). In Pakistan, Sohail and Hussain (2009) conducted their research with reference to the Lahore Stock Exchange. So, I intend to observe the behavior of stock returns in effect of Inflation, Exchange Rate, and Interest Rate, at Karachi Stock Exchange.

The objectives of the study are given as under: 
To study, whether there exists any relationship between stock returns and macroeconomic variables in context of Karachi Stock Exchange?

To find out the empirical results of the ties between stock returns and macroeconomic variables like, inflation, interest rate, exchange rate.

The research findings will not only guide the investors to study the pattern of volatility in stock returns at Karachi Stock Exchange, so that they can quickly react and alter their decisions when there is any change or move take place in macroeconomic factors to enhance their investment returns. While on the other side, this paper will also add value to the existing empirical studies conducted to study the impact of macroeconomic variables on stock returns.

\section{Literature Review}

Stock Markets have pivotal role in the whole financial system. There are only two possible sources for the firms, i.e. debt or equity. The financial institutions are the hub of debt resources while equity financing is done at Stock Markets. Stock Market is, in fact, the place where securities of listed companies are traded. In Pakistan, there are three stock exchanges at Karachi, Lahore, and Islamabad; but Karachi Stock Exchange (KSE) is the biggest in volume. There are several internal and external factors that influence the prices of stocks. Among these factors, the relationship between macroeconomic variables and stock market returns is always attractive for the researchers, and several studies have been conducted to read out the torque of the ties. Coleman and Tettey (2008) studied different macroeconomic variables (market return, term structure of interest rate, inflation, etc.) in Ghana Stock Exchange and concluded that all of the aforesaid variables have significant influence on stock returns. Similarly, if we caste a glance over each macroeconomic factor in the light of past literature, the findings of (Coleman \& Tettey, 2008) will be evident. Fraser and Groenewold (2000) examined the effect of exchange rate fluctuations on the volatility of Australian equity market, and found a substantial influence of exchange rate variations over stock returns. Ihsan, Ahmad, Haq, and Sadia (2007) studied the relationship of economic and financial variables of stock returns in Karachi Stock Exchange. After using multiple statistical models, they concluded that unanticipated realizations of economic and financial variables are significant determinants of movements in stock returns.

Aurangzeb (2012) examined the mutual relation of macroeconomic variables and stock returns, and indicated that foreign direct investment and exchange rate have significant positive impact on performance of stock market in South Asian countries while; interest rate has negative and significant impact on performance of stock market in South Asia. Furthermore, results also indicate the negative but insignificant impact of inflation on stock market performance in South Asia.

Sohail and Hussain (2009) examined long-run and short-run relationships between Lahore Stock Exchange and macroeconomic variables in Pakistan and drew the conclusion that there was a negative impact of consumer price index on stock returns, while, industrial production index, real effective exchange rate, money supply had a significant positive effect on the stock returns in the long-run. Adjasi (2009) tried to analyze the impact of macroeconomic uncertainty on stock-price volatility in Ghana. They are of the view that higher volatility in cocoa prices and interest rates increases volatility of the stock prices, whilst higher volatility in gold prices, oil prices, and money supply reduces volatility of stock prices. Wickremasinghe (2011) conducted a study to examine the causal relationships between stock prices and macroeconomic variables in Sri Lanka, in order to examine the validity of the semi-strong form of the efficient market hypothesis. Their results indicate that there are both short and long-run causal relationships between stock prices and macroeconomic variables.

The above referred studies intensely depict that macroeconomic variables have significant impact on Stock market returns and stock prices. Further, for a healthy and secure investment, the investors should have keen observation towards aforesaid macroeconomic variables, namely, inflation, interest rate, exchange rate, money supply, industrial production, etc. Keeping in view the above historical evidences, this study show the empirical relationship between macroeconomic variables and stock market returns.

\section{Data \& Methodology}

The study is conducted by incorporating monthly data for the period January 2007 to May 2017 which consists of 125 observations of KSE 100 Index data. The stock market return is taken as dependent variable and it is calculated through monthly index data using the following formula:

$$
R_{t}=\ln \left(\frac{P_{t}}{P_{(t-1)}}\right)=\ln \left(P_{t}\right)-\ln \left(P_{(t-1)}\right)
$$

Where, $R_{t}=$ market return at period $\mathrm{t} ; P_{t}=$ price at period $\mathrm{t} ; P_{t-1}=$ the price at period $\mathrm{t}-1, \ln$ is the natural $\log$. 
Here the linear affiliation between the dependent and the independent variables is resolute through the regression analysis and implications will be drawn based on the regression analysis (Kurihara \& Nezu 2006). The independent variables that affect the behavior of Stock Market Return are macroeconomic variables which include Inflation, Interest Rate and Exchange Rate. The monthly data of dependent variable (stock market return) is taken from Yahoo Finance (http://finance.yahoo.com/) and the secondary data regarding Inflation and Interest Rate is gathered from Trading Economics (http://www.tradingeconomics.com/) while Exchange Rate figures for PKR/USD are taken from (http://www.x-rates.com) and our objective is to find the impact of macroeconomic variables on stock market returns.

\subsection{Dependent Variable}

\subsubsection{Stock Returns}

The shares of listed companies are traded at different stock exchanges and as a result of this trading, investors get some return. This return may be in the form of dividend or capital gain arising from sale and purchase of these securities. Andreas G. Merikas and Anna A. Merika (2006); Coleman and Tettey (2008) said that Stock returns are directly linked with the prices of shares, which are influenced by inflation, interest rate and exchange rate.

\subsection{Independent Variable}

\subsubsection{Inflation}

Inflation is considered as one of the most important macroeconomic indicator. Liu and Shrestha (2008) conclude that there is a negative relationship between inflation and stock prices. During higher inflationary periods, investors expect disturbed profit patterns of listed firms; which results in a falling trend in the stock returns.

\section{Hypothesis 1}

H1: Inflation has significant negative effect on the stock market returns.

\subsubsection{Interest Rate}

Interest rate is also a key factor that influences stock returns. Increase in interest rate persuades the investors to shuffle towards bonds or saving schemes which causes stock prices to decrease. In contrary to the above, decrease in interest rate attracts the investors to invest their funds in equity market. While studying the Istanbul Stock Exchange, (Erdem, Arslan, and Erdem, 2005) confirmed that interest rate and stock returns are positively correlated.

Hypothesis 2

H2: Interest Rate positively affects the stock market returns.

\subsubsection{Exchange Rate}

Foreign currency exchange rate is a key determinant of economic activity of any country. Exchange rate fluctuations have a strong influence on the investment habits of the investors. Ibrahim and Aziz (2003) used exchange rate as an independent variable and concluded that there exists a negative relationship between equity and foreign exchange (forex) markets. In other words, a positive trend in exchange rate, shifts the investors from equity to forex market; while a negative fluctuation compels the forex investors to shuffle towards stock markets.

\section{Hypothesis 3}

H3: Exchange Rate has a positive significant relation with stock market returns.

\section{$3.3 \mathrm{Model}$}

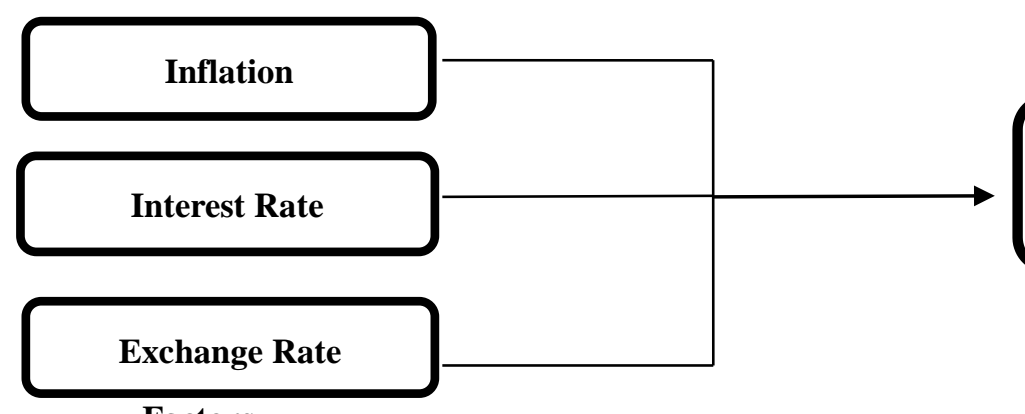

Factors
Stock

Market Return

Objective 


\section{Results}

In this section different statistical techniques are used to examine the empirical relationship between macroeconomic variables and stock market returns. First of all a brief descriptive analysis is given to provide an overview of the basic statistical findings:

Table 1. Descriptive statistics

\begin{tabular}{cccccc}
\hline Variable & Obs & Mean & Std. Dev. & Min & Max \\
\hline LR & 125 & .0113733 & .0716986 & -.4487961 & .1804674 \\
ER & 125 & 89.50783 & 14.39942 & 60.3533 & 107.4732 \\
IR & 125 & 10.148 & 2.772652 & 5.75 & 15 \\
INF & 125 & 9.62976 & 5.545345 & 6.32 & 25.33 \\
\hline
\end{tabular}

Note. $\mathrm{LR}=\mathrm{Log}$ Returns, ER=Exchange Rate, INF=Inflation, IR=Interest Rate.

Table 1 shows the descriptive analysis related to stock market; it shows total number of observations, minimum value, maximum value mean value and standard deviation of all the variables. These numeric figures will help to understand the data in proper manner. The dependent variable which is stock market return shows the low of -0.4487961 which was observed in November 2008 and shows the high of 0.180467 which was observed in February 2009, mean value of the dependent variable is 0.113733 and standard deviation is 0.716986 which shows the fluctuation in this variable. Inflation also affects the stock market because there is more fluctuation than interest rate. Lower rate of inflation 6.32 and high is 25.33 and the deviation between is 5.545345 . Exchange rate shows the low of 60.3533 and high of 107.4732 in last 6 years this increase is mainly due to economic crises so the rupee loses its strength against the dollar. Interest rate touch the low of 5.75 and the peak of 15.0 in the last 6 years, mean value shows the value of 10.148 and the standard deviation of 2.772652 which suggest that there is stability in this variables compare to the dependent variable.

A macro-econometric model which is a modified version of Omole and Falokun (1996) for the more empirical analysis of the relationship between the selected macroeconomic indicators and the performance of the stock market index is use. The original model is an estimation of an unrestricted investment equation of the general accelerator type which included cash flows, leverage ratios - debt-capital and debt-equity ratio as additional regressors. Thus, we specify the following empirical model to be estimated:

$$
L N(R t)=\beta 0+\beta 1 I N F+\beta 2 E R+\beta 3 I N T+\varepsilon
$$

Where, LN (RT) - the log return of the Karachi stock exchange index; INF - the rate of inflation; ER - the exchange rate; INT -the interest rate is the coefficients of the variables and $\varepsilon$ is the error term.

We use the regression analysis to test our hypothesis, whether there exists any significant relationship between stock market return and states macroeconomic indicators

Table 2. Analysis of variance

\begin{tabular}{lccc}
\hline Source & SS & df & MS \\
\hline Model & .064652687 & 3 & .021550896 \\
Residual & .572793055 & 121 & .004733827 \\
Total & .637445742 & 124 & .005140691 \\
\hline Number of obs $=125$ & & & \\
$\mathrm{~F}(3,121)=4.55$ & & & \\
Prob $>\mathrm{F}=0.0047$ & & & \\
R-squared $=0.1014$ & & & \\
Adj R-squared $=0.0791$ & & & \\
Root MSE $=.0688$ & & & \\
\hline
\end{tabular}

Table 3. Results for the regression(depended variable is stock return)

\begin{tabular}{lllllll}
\hline Log return & Coef. & Std. Err. & $\mathrm{T}$ & $\mathrm{P}>|\mathrm{t}|$ & [95\% Conf. & Interval] \\
\hline ER & .000166 & .0005088 & 0.33 & 0.745 & -.0008413 & .0011733 \\
IR & .008608 & .0038172 & 2.26 & 0.026 & .0010509 & .0161652 \\
INF & -.0065164 & .0019712 & -3.31 & 0.001 & -.0104189 & -.0026139 \\
_cons & -.0280902 & .0610205 & -0.46 & 0.646 & -.1488963 & .0927159 \\
\hline
\end{tabular}

Note. ER=Exchange Rate, INF=Inflation, IR=Interest Rate, Cons= Constant value. 
Table 2 represents the empirical findings states that the overall model of KSE return is explain by inflation, interest rate and exchange rate in regression equation is approximately $11 \%$. The value of S.E is quite low having value $7 \%$. The value of F-test $(3,121)$ is 4.55 . In the table 3 the coefficient of exchange rate interest rate and inflation respectively are $.01 \%, .8 \%$ and $-.6 \%$. The value shows that exchange rate and interest rate have positive impact on log returns of the Karachi stock exchange and inflation have negative impact on log returns, on the influence of inflation, interest rate and exchange rate on stock market returns for the period of 2007-2017. After applying the regression model the above results are generated in which coefficients of all variables with their t-statistics and p-value were observed. We applied serial LM test to calculate the value of Durbin Watson which suggest the value of (1.9041) as the DW value this means there is no auto correlation exists in this model and this model is good for analysis. Exchange rate shows the positive and significant impact on stock prices. As mentioned in the theoretical background Increase in exchange rate was also increase the purchasing power of foreign buyers because they invest the same amount in their local currency but after the conversion the amount will increase and they can purchase more stocks than earlier so ultimately it gives the more liquidity in the market. The another reason of this positive impact is this whenever the foreign exchange rate increases investors were shift their investment from the foreign exchange market to other markets due to increase of risk in foreign exchange market. This coefficient is not strong enough to manipulate the market because whenever the exchange rate increase local investors can move from stock market to foreign exchange market to enhance their returns. Inflation shows the negative relationship with stock market returns the coefficient shows that when $1 \%$ increases in inflation the stock market returns decreases by $0.7 \%$. Interest rates in the economy increases the negative trend in the stock market because interest rates gives the opportunity to the investors to move their investment from stock market to bank deposits and gain the maximized returns. As interest rates which offered on deposit decreases investors find it more worthwhile to invest their money into other avenues such as the stock exchanges and real estate etc. A similar but opposite behavior is witnessed in the case of an increase in interest rates. When interest rate increases people find it more profitable to keep their money in the bank than to invest it in risky avenues such as the stock market.

\section{Conclusion}

The purpose of this was to empirically investigate the effects that macroeconomic indicators do exact on the performance of stock markets using the KSE data. The logic behind the study is that globally stock markets are regarded as financial institutions where funds can be raised in order to finance investment so as to achieve high-economic growth and hence development. Most of the studies carried out stock markets have rather concentrated on its linkage with economic growth and mostly in advanced countries. It was therefore deemed appropriate to examine the impact of macroeconomic fundamentals on the performance stock markets from a small country dimension as these fundamentals have not been stable over the years. Inflation was found to have adverse effect on the performance of the market. Results of this study agree with the study of (Fama, Rapach, Wongbangpo and Sharma), Chopin and Zhong who found that negative relationship between stock price and inflation but result indicated that the present inflation level does not have any effect on market performance but rather it takes time for the market to react to changes in the inflation rate. The results of exchange rate indicate that the investors of KSE market not care about the exchange rate variation they prefer to invest in market rather than foreign currency.

With these results it is important to highlight that there is the need to implement practical macroeconomic policies in order for a country to derive maximum benefits from stock markets. In order to enable the capital market in general and stock market in particular to take full advantage of the various opportunities and cope with challenges, interest rates, inflation, must be reduced. This must be done in relation to appropriate monetary policies to ensure macroeconomic stability.

The important contribution of this study is its emphasis on macroeconomic variables and stock market performance in a developing country, since most studies have concentrated on stock markets and economic growth in advanced economies. The study also gives the cutting-edge information of the stock market and selected macroeconomic indicators.

\section{Limitation of Study and acknowledgments}

The main limitation is the use of one country. We therefore hope to broaden the study more than one country data permitting in order to draw stronger conclusions. TENG Jian-Zhou Acknowledges Financial support from the China's National Social Science Research grant(16BTJ025).

\section{References}

Adjasi, C. (2009). Macroeconomic uncertainty and conditional stock-price volatility in frontier African markets 
Evidence from Ghana. The Journal of Risk Finance, 10(4), 333-349. https://doi.org/10.1108/15265940910980641

Allen, F., \& Santomero, A. (1996). The Theory of Financial Intermediation (pp. 96-32).

Andreas, G. (2006). Stock prices response to real economic variables; The case of Germany. The Journal of Managerial Finance, 446-450.

Aurangzeb. (2012, September). Factors Affecting Performance of Stock Market: Evidence from South Asian Countries. International Journal of Academic Research in Business and Social Sciences, 2(9), 1-15.

Bekiros, S., \& Georgoutsos, D. (2008). Extreme returns and the contagion effect between the foreign exchange and the stock market: Evidence from Cyprus. Applied Financial Economics, 18(3), 239-254. https://doi.org/10.1080/09603100601018823

Coleman, A. K., \& Tettey, K. A. (2008). Impact of macroeconomic indicators on stock market performance; The case of the Ghana Stock Exchange. The Journal of Risk Finance, 9(4), 365-378. https://doi.org/10.1080/09603100601018823

Erdem, C., Arslan, C. K., \& Erdem, M. S. (2005). Effects of macroeconomic variables on Istanbul stock exchange indexes. Applied Financial Economics, 987-994. https://doi.org/10.1080/09603100500120365

Fraser, P., \& Groenewold, N. (2000). The Effect of Exchange Rate Shocks on the Volatility of Australian Sector Excess Returns. Applied Economics Letters, 7, 77-81. https://doi.org/10.1080/135048500351852

Hussainey, K., \& Ngoc, L. K. (2009). The impact of macroeconomic indicators on Vietnamese stock prices. The Journal of Risk Finance, 10(4), 321-332. https://doi.org/10.1108/15265940910980632

Ibrahim, M. H., \& Aziz, H. (2003). Macroeconomic variables and the Malaysian equity market A view through rolling subsamples. Journal of Economic Studies, 30(1), 6-27. https://doi.org/10.1108/01443580310455241

Ihsan, H., Ahmad, E., Haq, M. I., \& Sadia, H. (2007). Relationship of Economic and Financial Variables With Behaviour of Stock Returns. Journal of Economic Cooperation, 28(2), 1-24.

Liu, M. H., \& Shrestha, K. M. (2008). Analysis of the long-term relationship between macroeconomic variables and the Chinese stock market using heteroscedastic cointegration. Managerial Finance, 34(11), 744-755. https://doi.org/10.1108/03074350810900479

Pal, K., \& Mittal, R. (2011). Impact of macroeconomic indicators on Indian capital markets. The Journal of Risk Finance, 12(2), 84-97. https://doi.org/10.1108/15265941111112811

Serfling, M., \& Miljkovic, D. (2011). Time series analysis of the relationships among (macro) economic variables, the dividend yield and the price level of the S\&P 500 Index. Applied Financial Economics, 21(2), 1117-1134. https://doi.org/10.1080/09603107.2011.562167

Sohail, N., \& Hussain, Z. (2009). Long-Run And Short-Run Relationship Between Macroeconomic Variables And Stock Prices In Pakistan. The Case of Lahore Stock Exchange. Pakistan Economic and Social Review, 47(2), 183-198.

Wachter, J. A. (2013). Can time-varying risk of rare disasters explain aggregate stock market volatility? The Journal of Finance, 987-1035. https://doi.org/10.1111/jofi.12018

Wickremasinghe, G. (2011). The Sri Lankan stock market and the macroeconomy: an empirical investigation. Studies in Economics and Finance, 28(3), 179-195. https://doi.org/10.1108/10867371111141954

Wongbangpo, P. A. (2002). stock market and macroecnomic fundamental dynamic interactions. ASEAN-\% Countries Journal of Asian, 13, 27-51. 


\section{Appendix}
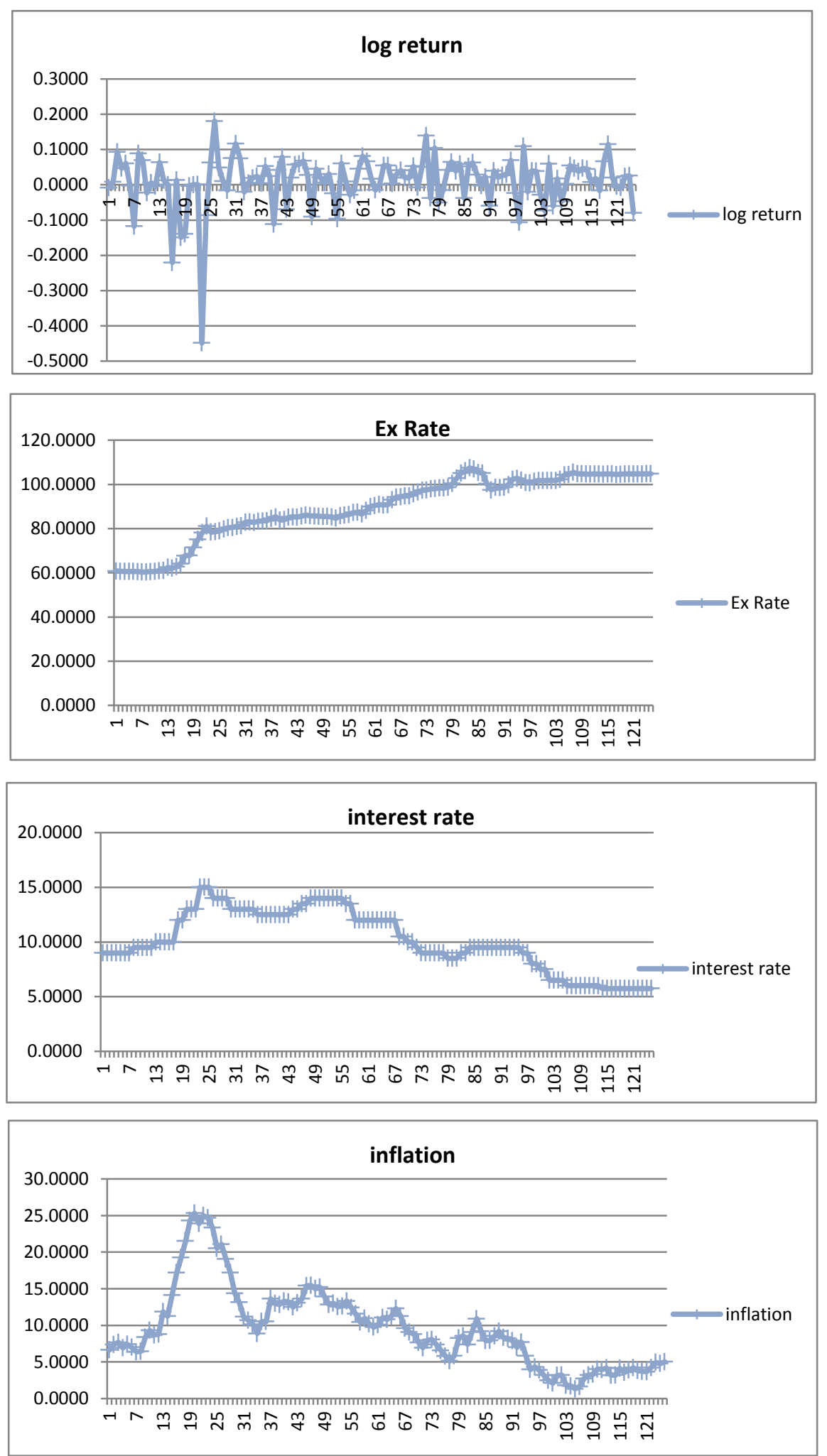

\section{Copyrights}

Copyright for this article is retained by the author(s), with first publication rights granted to the journal.

This is an open-access article distributed under the terms and conditions of the Creative Commons Attribution license (http://creativecommons.org/licenses/by/4.0/). 